\title{
IMPLEMENTING DOE GUIDANCE FOR HAZARDS ASSESSMENTS AT ROCKY FLATS PLANT
}

\author{
Author: Gary A. Zimmerman \\ Company: EG\&G Rocky Flats, Inc. \\ SUMMARY
}

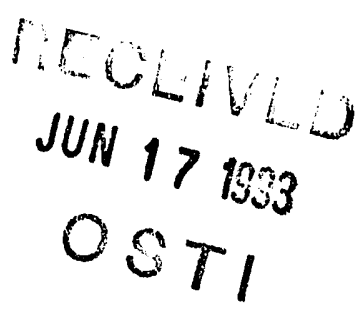

Introduction

Hazards Assessments are performed for a variety of activities and facilities at Rocky Flats Plant. Prior to 1991, there was no guidance for performing Hazards Assessments. Each organization that performed Hazards Assessments used its own methodology with no attempt at standardization. In 1991, DOE published guidel ines for the performance of Hazards Assessments for Emergency Planning (DOE EPG 5500.1, "Guidance for a Hazards Assessment Methodology"). Subsequentiy, in 1992, DOE published a standard for the performance of Hazards Assessments (DOESTD-1027-92, "Hazard Categorization and Accident Analysis, Techniques for Compliance with DOE Order 5480.23, Nuclear Safety Analys is Reports"). Although these documents are a step in the direction of standardization, there remains a great deal of interpretation and subjective implementation in the performance of Hazards Assessments. Rocky Flats Plant has initiated efforts to develop a uniform and standard process to be used for Hazards Assessments.

\section{Discussion}

In an attempt to standardize the approach to be used for Hazards Assessments for Emergency Planning, DOE published guidelines in November, 1991. This guidance document was revised in June, 1992, and retitled', "Guidance for Hazards Assessment" This guidance document provides a means for implementing DOE Order 5500.3A, "Planning and Preparedness for Operational Emergencies". DOE conducted several workshops in 1992 to assist Energy Facility Contractors in implementing this guidance.

In December of 1992, DOE issued the standard DOE-STD-1027-92, "Hazard Categorization and Accident Analysis Techniques for Compliance with DOE Order 5480.23, Nuclear Safety Analysis Reports". This DOE standard superseded the draft standard DOE-STD-1013-92 and provides guidance for complying with DOE Order 5480.23, "Nuclear Safety Analys is Reports". In some respects, DOE standard 1027 is not as specific in regard to performing Hazards Assessments as is the DOE guidance document for Emergency Planning while in others it is more specific. The EPG guidance document and the DOE standard are not inconsistent. DOE 1027 provides a graded approach for evaluating hazards. However, it is left for the Energy Facility Contractors to determine how best to implement these documents when performing Hazards Assessments.

In the fall of 1992, the Emergency Planning Department at Rocky Flats Plant felt that implementation of the DOE guidance for Hazards Assessments involved more than just their own organization. Realizing that other departments and organizations performed Hazards Assessments, a meeting was held to see what steps 
could and should be taken to standardize the process. It was generally agreed that something needed to be done to eliminate the duplication of effort and redundancy that presently exists. After that meeting, Rocky Flats management assigned the responsibility for developing a standardized process to the organization known as Transition Standards Identification Program (TSIP).

TSIP was organized to respond to the Defense Nuclear Facilities Safety Board (DNFSB) question concerning what standards apply to a facility being reviewed for restart operations. Although TSIP is a staff organization, there is a TSIP Steering Committee to review the activities of the staff and piovide direction. Members of the TSIP Steering Committee are Directors or Assistants to Assistant General Managers in the Rocky Flats Plant line organization.

The TSIP steering committee formed two subcommittees to deal with the standardization process. Membership of the two subcommittees consists of representatives from the various organizations that perform Hazards Assessments The two subcummittees are the Facility Characterization Working Group (FCWG) and the Hazards Assessment Working Group (HAWG).

The FCWG is chartered to develop the criteria and the process for performing a Facility Characterization. In light of the change in mission at the Rocky Flats Plant, a Facility Characterization is considered to be necessary to determine the design basis, the existing conditions, the current and planned activities, and eventual use of the building. Once a Facility Characterization exists, a Hazards Assessment, Safety Analysis, Unreviewed Safety Question Determination, or other evaluation could be performed.

The HAWG is chartered to develop the criteria, methodology, and the process for performing a Hazards Assessment. The methodology needs to be such that it would satisfy the requirements of the DOE standards and guidance documents, and any and all other regulatory requirements, and meet the needs of the various organizations that currently use them. Both working groups were directed to do a pilot study of a selected facility to evaluate the processes that they develop.

Simultaneously, those organizations needing Hazards Assessments are continuing to perform them using their own methodology and techniques subject to the guidance of the DOE documents. The Emergency Planning Department has committed to implementing the DOE guidance and is proceeding to perform Hazards Assessments on those facilities directed by Rocky Flats Plant management as part of the Emergency Planning Zone (EPZ) project with the State of Colorado. The Hazards Assessment for one facility has been completed and is undergoing technical review at the present time. Work on the Hazards Assessment for a second facility has commenced and is approximately 20-25 percent complete. Other organizations are reviewing their processes for performing Hazards Assessments and planning how best to implement DOE-STD-1027-92.

\section{Conclusions}

Standardized Hazards Assessments are expected to reduce the duplication of effort and redundancy that presently exists. DOE Emergency Planning Guidance (EPG) is the first step towards standardizing the process. The EPG is being implemented by the Emergency Planning Department and is being used by TSIP to develop a standardized process for the Rocky Flats Plant. 


\section{DISCLAIMER}

This report was prepared as an account of work sponsored by an agency of the United States Government. Neither the United States Government nor any agency thereof, nor any of their employees, makes any warranty, express or implied, or assumes any legal liability or responsibility for the accuracy, completeness, or usefulness of any information, apparatus, product, or process disclosed, or represents that its use would not infringe privately owned rights. Reference herein to any specific commercial product, process, or service by trade name, trademark, manufacturer, or otherwise does not necessarily constitute or imply its endorsement, recommendation, or favoring by the United States Government or any agency thereof. The views and opinions of authors expressed herein do not necessarily state or reflect those of the United States Government or any agency thereof. 

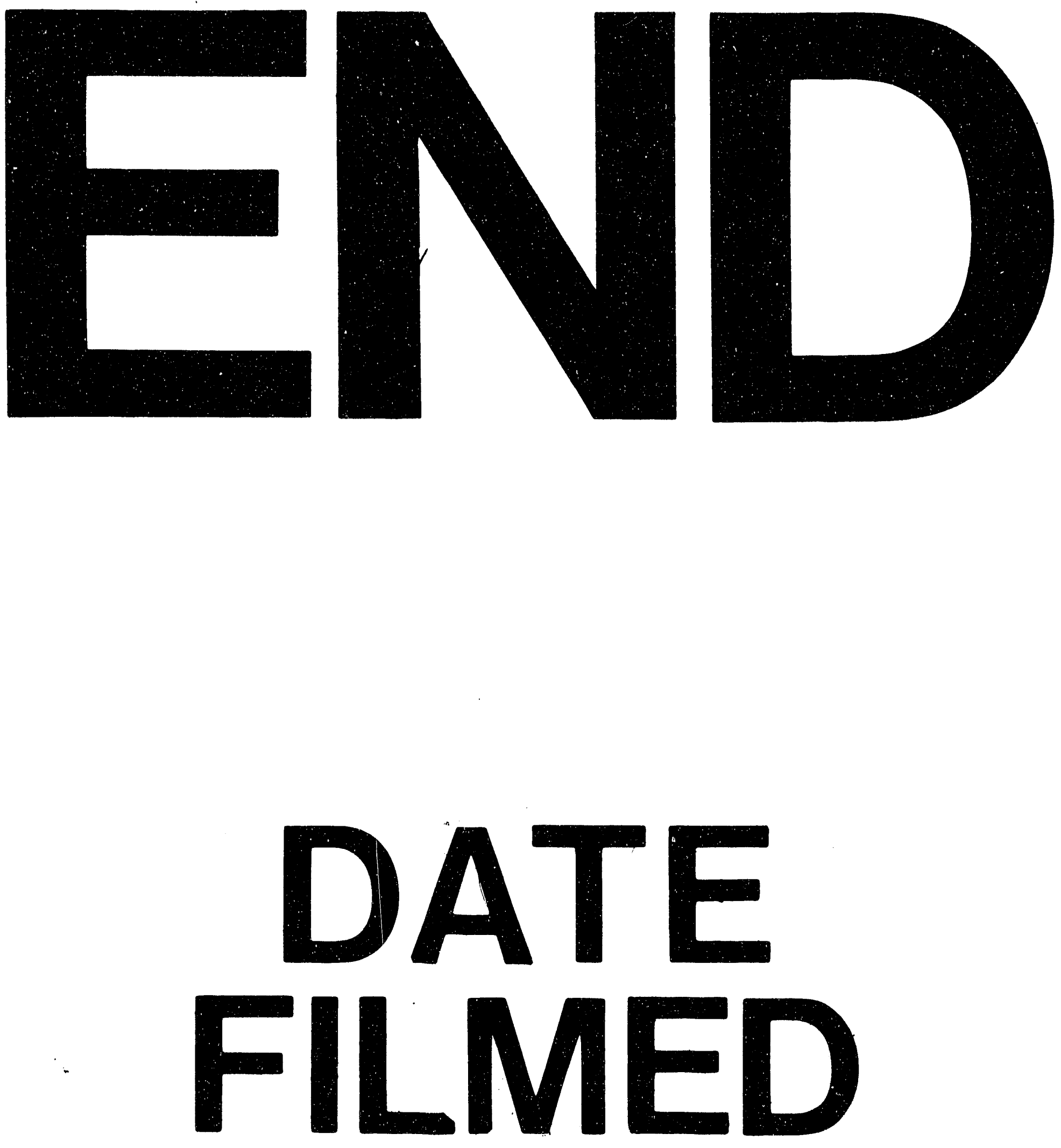

1

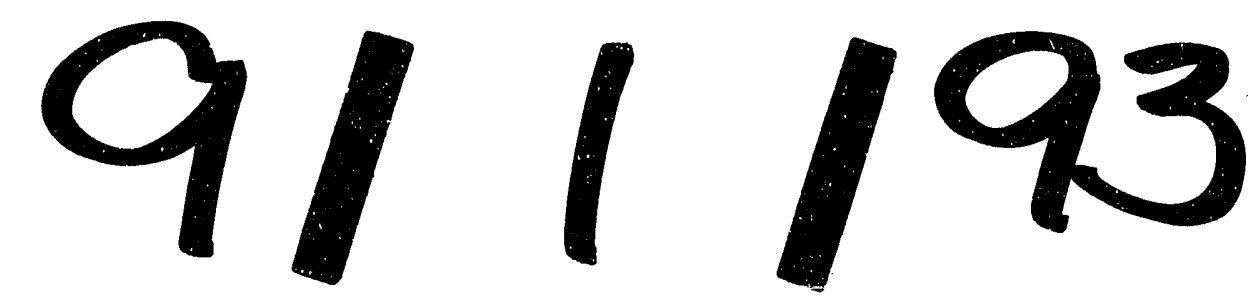


